\title{
Setting a Benchmark for REIT Performance in Malaysia
}

\author{
${ }^{1}$ Olusegun Olaopin Olanrele*, ${ }^{2}$ Rosli Said and ${ }^{3}$ Md Nasir Daud \\ Department of Estate Management, Faculty of Built Environment, University of Malaya, 50603 Kuala Lumpur, Malaysia \\ 1olanrele@ siswa.um.edu.my*, ${ }^{2}$ rosli_alambina@um.edu.my, ${ }^{3}$ mdnasir@um.edu.my
}

\begin{abstract}
The percentage performance of a REIT is not the most important but the reliability of the performance in absolute terms to a relevant index or benchmark is key to assessing REIT index or benchmark. This paper focuses on the construction of a performance benchmark for REIT sector in Malaysia. The study explores the literature on performance and benchmarking, appraises REIT performance analyses as presented in past studies, and proposes REITs return benchmark using Time series forecast. The study adopts a quantitative analysis approach. Ten listed conventional REITs were purposively selected to reflect diversity in portfolio and location. Data was extracted from annual reports of selected REIT companies through their websites for an eight-year transaction period (2006-2013). Time series regression was performed on the collected data from the listed REITs to establish a linear model for the forecast of REIT return at any period that can serve as a benchmark for the REITs. The study found that Malaysian REIT performed 27.5\% lower than the forecast for 2013 but outperformed the KLCI index. M-REIT has the capacity to do better than the $6.8 \%$ recorded for 2013. The study did not extend to the Islamic REITs in Malaysia.
\end{abstract}

Keywords: benchmark, dividend, performance, REIT return, time series

\subsection{INTRODUCTION}

Real Estate Investment Trust (REIT) is traditionally a closed end fund that focuses on holding/investing in real estate properties and related assets of mortgage in both real estate and mortgage (Chan et al., 2003). However the change in tax law in the United States of America (USA) causes REIT to be seen as operating companies through the provision of real estate management services even to their own tenants. Nevertheless, real estate asset holding still remains as the distinguishing part of assets of REITs. Rupert Nabarro (quoted in Parker, 2011) regards REITs as a fast growing stock globally in different stock exchanges. REIT has become a globally accepted form of investment in real estate assets (Parker, 2011). Presently, REIT is a sector with substantial impact in various stock markets across the world with 858 REIT companies in 37 countries accounting for USD\$1.4 trillion (EPRA, 2014).

The performance of REIT as a securitised real estate investment with real property or mortgages as its underlying asset has been related to two important factors which are (i) the pricing of REIT stocks in the stock market (share price) and (ii) the income from the underlying real property assets. While the share price movement in the stock market is an indication of value/capital appreciation, the income from underlying property assets determines the dividend distribution. These elements are quantitatively and accurately measured in most cases (Chan et al., 2003). Parker (2011) stated that the appropriate basis for performance measurement is the yield (rate of return). Therefore the dividend paid is converted to yield as a percentage of the initial offering price (IPO) of REIT shares to represent REIT return. Real Estate Investment Trust (REIT) performance can also be literally explained in terms of its operational success as reflected in its profitability to the investors. REIT markets have proved extremely successful in U.S. and Australia, with growth potentials in the "new" REIT markets in Asia and in Europe (Hoesli \& Lizieri, 2007).

Performance measurement can be viewed from various perspectives such as quality service, customer satisfaction, cost efficiency, or income and return generation (Kotler, 1984; Neely, 1994; Slack, 1991). The system of performance measurement explores issues such as internal, external, financial and non-financial to arrive at a judgment (Kapplan \& Schwartz, 1995; Lee et al., 
2005). Performance measurement/return analysis can be in respect of individual property, asset class comprising a number of properties or portfolio of different asset classes (property, mortgage and other stocks). Thus the principle and methods are similar. In the real world, dividend distribution to unit holders connotes the real return on investment while capital gain through price appreciation of stocks is an abstraction that comes to reality only if the stock is sold at the point of its price appreciation. Given that for the purpose of this study capital appreciation is considered merely as a reward to shareholders for the risk taken to have invested their capital/fund in any chosen stock it thus treated dividend as the true and ascertained return on investment.

The fluctuation of REIT performance in terms of returns over the years has been identified as cyclical in trend. Chan et al. (2003) summarised that REIT outperformed the stock market at specific time periods with a risk adjusted return but underperformed the stock market in the long run. The unstable performance trend was traced to the property market behaviour which exhibits cyclical returns with a period of boom always followed by periods of bull and recovery and recession in a cyclical way. REIT performance is also a function of type, whether equity or mortgage. Equity REIT has been proven to have superior performance over mortgage or hybrid (Chan et al., 2003; Grupe \& DiRocco, 1999). The focus of this study is to forecast a REIT return which can serve as sectoral benchmark for REITs in Malaysia based on the past performances of M-REIT. Dividend-based return of REIT reflects a time series data which is usually distributed on a quarterly basis. As a result, the effect of market situations at different times is reflected in the distribution. Therefore, this study considers a prediction of expected REIT return in consideration of the probability, seasonality and market trend as they affect dividend distribution to make a forecast of a benchmark for REIT return. While property market inefficiency makes it difficult for prices to reflect full available market information, time series analysis of return and market trend is unlikely to give an abnormal return (Parker, 2011). This study contributes to the existing literature with its special focus on sectoral benchmark setting with reference to actual return for REIT performance. It will also reveal the industry, the inherent capacity of the sector to do better in terms of performance in the area of dividend distribution. Investors too will be able to predict the performance expectation for the firms which will make the REITs achieve optimum level of dividend based return performance.

\subsection{LITERATURE REVIEW}

A REIT is an entity that invests primarily in real estate and qualifies for special tax treatment, providing a conduit for earnings to be taxed at the investor level and not at the entity level (EPRA, 2012). REITs are expected to own, operate, acquire, develop and manage real estate assets and/or provide related services. Oreagba (2010) defines REIT as "a company that owns, and operates income producing real estate, whose shares are publicly traded in a way similar to any other stock". It owns and manages investment grade and income producing real estate properties such as office buildings, residential buildings, shopping malls, tourism related facilities, healthcare facilities, industrial facilities and infrastructures (FMI, 2010). Corgel et al. (1995) and Wong (2004) identified REIT as "investment tool to create a flow of funds from investors to the real estate and property sector of the country. REIT has the attributes of both the stock and bond and is thus regarded as a hybrid of the two (Ong et al., 2011). REIT increases strength from the pool of resources gathered from investors and invests into high profile and high value property for greater return as many investors may not individually be able to invest in a huge real estate portfolio (Wong, 2004). Therefore, for the purpose of this paper, REIT is defined as "a company or corporation registered with a stock exchange which invests its fund (in a manner like a mutual fund) on income generating real estate products (property/asset), shares of property companies and real estate mortgages; generates its income from property investment and distributes almost all its revenue before tax to its investors/shareholders in the form of dividends with little provision for re-investment". The common features in the definitions of REIT are:

i. A registered company, association, trust or corporation

ii. Investment in income yielding real estate properties, and or real estate mortgage

iii. Generate revenue from real estate properties

iv. Distribution of revenue before tax to investors in the form of dividend

Designed to make funds available for real estate and stimulate real estate development and financing, REIT as a real estate investment vehicle could achieve its goals in two ways. First, by making funds available for immediate acquisition of real estate products from property developers, who will have their money in bulk and in time and move on to develop more or repay their development loan thereby making such fund available to developers for another project. Second, REITs through mortgage REIT can buy mortgage-backed securities thereby releasing funds for more mortgage activities. In Malaysia, as revealed in annual reports of REIT companies over the years, over $90 \%$ of the REIT operations have focused on equity REIT; acquisition, owning and managing of income-yielding real estate properties. In other countries such as USA, REITs are reported to have been involved in real estate development to increase their portfolio (Cunningham \& Ramey, 2006). Every investor's wish is to buy an asset today that guarantees capital appreciation tomorrow while yielding a competitive annual income in the form of dividend. Guaranteed capital appreciation is one of the peculiar features of real estate assets. 
The primary focus of REIT was initially on property asset acquisition with the REIT fund and there are investment restrictions in the various REIT laws across the REIT markets to investment in real estate acquisition and mortgage instrument. However, the growth of earnings became an important object in the tail end of 1960s and a short term loan to finance acquisition of properties became important. Between 1968 and 1970, a good number of new REITs were mortgage REITs with focus on mortgage lending against direct property investment (Chan et al., 2003). However, there are limitations to REIT as a funding source for direct real estate development which has to do with an understanding of the saturation point of the property market in order to avoid excess supply. The model outlook of any REIT is developed in line with the jurisdictional rule, regulations and law guiding REIT establishment and operations. This is reflected in focus, sector or environment of REIT (Parker, 2011). REIT acquisition may target individual real estate owners, or property developers and even real estate funds. They could adopt internal or external management strategy and can be property sector specific or geographically focused. Irrespective of the focus or management strategy, a typical REIT structure is presented in Figure 1 below.

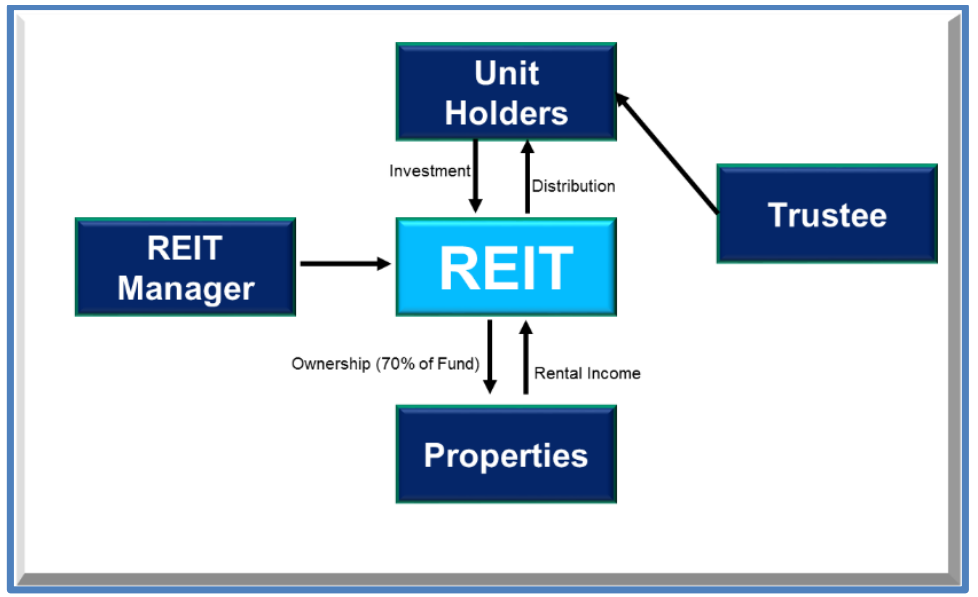

Figure 1: REIT structure

Source: Collier (2013)

\subsection{History and Development of Malaysian REIT (M-REIT)}

REIT started in the United States in 1960. Since then more countries around the world have established REIT regimes at different times. The spread of the REIT approach to real estate investment around the world has increased awareness and acceptance of investing in global real estate securities. The recognition of the advantages REITs offer to property investors, and the investments they attract to the world's cities have underpinned the REIT regimes growth (EPRA, 2012). Malaysia is the first Asian country to introduce REIT (Lee \& Ting, 2009). It succeeds its pre-cursor, the Property Trust Fund, existed since 1989. The Malaysian Property Trust Fund (PTF) was developed in line with the Australian Listed Property Trust (LPT) model as a basis to set up the regulatory framework (Ahmad \& Izah, 2010; Hwa, 2008). Following the Asian economic crisis of 1997, other Asian countries established REIT market with Japan pioneering the movement in 2001, followed by Singapore in 2002, Taiwan in 2004, and Hong Kong in 2005. Japan has the most developed REIT market while Singapore's REIT market appears to be the most dynamic in Asia.

Bank Negara Malaysia (the Malaysian Central Bank) approved the first regulatory framework under Company Act 1965 while Securities Commission Act of 1983 governed the establishment and operations of Property Trust Funds. The Securities Commission became regulator later on in 1991 (Hwa, 2009), and further guidelines were published by the Specific Securities Commission in 1995 (Ong et al., 2011). The Securities Commission introduced a consultation process for property related trust funds in 1999 which leads to a revised guideline in 2002. Malaysian REIT in modern form came into existence in 2005 following the guidelines of the Securities Commission the same year. This particular amendment stated the minimum fund size of RM100 million for a REIT to be formed in Malaysia. The management company is entitled to foreign effective equity, limited to the maximum of 70\% (Ong et al., 2011). Furthermore, real estate investment trust can either be listed or unlisted in Malaysian Stock Exchange. However, relevant listing and shareholding prerequisites issued by KLSE must be complied with by the listed REIT(s). According to Finance Act 2004, real estate investment trusts are enabled to indulge the tax treatment as follow:

1. The undistributed income will be taxed at $28 \%$ while distributed income will be tax exempted

2. The tax payable at $28 \%$ will be withheld by real estate investment trusts for non-residents

3. Accumulated income that has been taxed and subsequently distributed is eligible for tax credit 
Besides, stamp duties are exempted on all transfers of real property for REITs as stated in Finance Act 2004. Real property gains taxes are also exempted for property sale transaction from owners to REITs (Ahmad \& Izah, 2010).

Today, Malaysian REIT (M - REIT) has thirteen (13) conventional REITs and four (4) Islamic REITs on the Board of Bursa Malaysia as presented in Table 1 .

Table 1: Listed REITs in Malaysia

\begin{tabular}{|c|l|c|c|c|}
\hline S/N & \multicolumn{1}{|c|}{ Company Name } & Acronym & Year Established & Type \\
\hline 1 & AmFirst REIT & AMFIRST & 1989 & Conventional \\
\hline 2 & AmanahHartaTana PNB & AHP & 1990 & Conventional \\
\hline 3 & Starhill REIT & STAREIT & 2005 & Conventional \\
\hline 4 & UOA REIT & UOAREIT & 2005 & Conventional \\
\hline 5 & Axis-REIT & AXREIT & 2005 & Islamic \\
\hline 6 & Hektar REIT & HEKTAR & 2006 & Conventional \\
\hline 7 & Tower REIT & TWRREIT & 2006 & Conventional \\
\hline 8 & AL-Aqar Healthcare REIT & ALAQAR & 2006 & Islamic \\
\hline 9 & AmanahRaya REIT & ARREIT & 2007 & Conventional \\
\hline 10 & Atrium REIT & ATRIUM & 2007 & Conventional \\
\hline 11 & AL-Hadharah Boustead REIT & BSDREIT & 2007 & Islamic \\
\hline 12 & Quill Capital Trust & QCAPITA & 2007 & Conventional \\
\hline 13 & Sunway REIT & SUNREIT & 2010 & Conventional \\
\hline 14 & CapitalMalls Malaysia Trust & CMMT & 2010 & Conventional \\
\hline 15 & Pavilion REIT & PAVREIT & 2010 & Conventional \\
\hline 16 & IGB REIT & IGBREIT & 2012 & Conventional \\
\hline 17 & KLCC REIT & KLCC & 2013 & Islamic \\
\hline
\end{tabular}

Source: Bursa Malaysia Securities (December, 2013)

\subsection{Overview of M-REIT Performance Analysis}

Investment performance measurement is an objective assessment of income, capital appreciation and investment risk in comparison with indices or benchmark. Since the performance of REITs is determined by the type of investment companies focus on, which is basically divided into Equity REIT, Mortgage REIT and Hybrid REIT - which invest in both equity and mortgage debts (Grupe \& DiRocco, 1999), income distribution in the form of dividend that is regarded as the reward to investors is a measure of performance of REIT as it is for any other investment in the stock/capital market and could be measured in percentages (\%) or money units. Parker (2011) opined that the appropriate basis for performance measurement is the yield (rate of return).

REIT performance has been extensively researched across the global REIT markets and in Malaysia with the consensus that M-REIT outperforms the stock market, the usual benchmark. Grupe and DiRocco (1999) in a study of REITs in the United States found the equity REITs outperforming the market. According to Havsy (2012), REITs in the United States outperformed the S\&P 500 index with a long term yield of 7-8\%. Okunev and Wilson (2008) adopted a modelling approach to predict excess asset return and also concluded that REIT provides excess return. Ong et al. (2011) in their study of Malaysian REIT found M-REIT having superior performance over other stocks and the market index and also reported that the superior performance can be sustained by MREIT. Newell and Osmadi (2009) also found Malaysia REIT outperforming the market, the KLCI. In a comparative study of Malaysia and UK REITs, Alias and Soi Tho (2011) found a similar result with both markets. Pham (2013) concurred with the findings in the FMI report of 2010 that most Asian REITS outperform their respective stock markets including Malaysia REIT having $4.1 \%$ to $9.3 \%$ dividend return. The study concluded that Asian REIT markets have higher returns with lower risks.

On the contrary, there have been reports of REITs underperforming their benchmarks. Osmadi (2007) in a study of the Malaysian property trust funds (PTFs) for the period 1991-2005 prior to the PTFs' conversion to modern REIT regime concluded that the PTFs underperformed the stock market index, KLCI. Newell et al. (2002) in a similar study found only one out of the four (4) companies studied to have outperformed the KLCI. In an earlier study, Ooi and Liow (2003) did not find any empirical evidence of higher return from real estate stocks to other stocks in Asian markets. Ong et al. (2012) also reported dual findings of both negative and positive outperformance of Malaysian REITs depending on the measurement tool adopted. While Treynor and Sharpe Indexes revealed underperformance during and after the global financial crisis (GFC), Jensen Alpha presented superior performance of M- 
REIT to the market (KLCI). Taiwan REIT was found to have underperformed the construction sector shares on risk adjusted return (Sharpe ratio) basis (Peng \& Newell, 2012).

The commonality of the past studies is that the stock market index has been adopted as benchmark. The stock index is an estimate of the capital gains of the stock in respect of the price changes in the trading floor of the stock exchange which is being affected by factors different from those that affect income from real estate that is the bone of REIT investment. The real income from REIT investment is the dividend to unit holders that will always reflect the income generation capability of the underlying real estate asset of REITs. Therefore, this study considers the prediction of expected dividend return a benchmark for REIT performance and this is the focus of this paper.

\subsection{Index and Benchmarking}

Comparative analysis and forecast are usually employed in investment return performance analysis by fund managers and investment decision makers. Asset management and portfolio teams of a REIT company use comparative and forecast to monitor investment performance (Parker, 2011). Hiriyappa (2008) said that the ability of investors to forecast performance helps both investors and managers in decision making. Parker (2011) further affirmed that REIT performance is related to benchmark or market index and stated that the ability of a real estate portfolio manager to match or surpass an index or benchmark is affected by the heterogeneity and information asymmetry of a property market. Past studies adopted risk return approach with an emphasis on risk adjusted returns (Newell et al., 2002; Newell \& Osmadi, 2009; Peng \& Newell, 2012; Pham 2013). Some other studies have compared different REIT volatility with different indices like Sharpe ratio, Treynor index, S\&P 500 index, KLCI index or KLPI index. Some others find the correlations between REIT and other investment vehicles while some discuss the contribution or impact of different determining factors of REIT performance on dividend (as a measure of performance). Resort to value weighted portfolio such as S\&P 500 index as a proxy is not uncommon in REIT performance assessment but usually results in higher Jensen Index than the equity weighted portfolio (Chan et al., 1990; Han \& Liang, 1995; Titman \& Warga, 1986).

The percentage performance of a REIT is not the most important but the reliability of the performance in absolute terms to a relevant index or benchmark is key to assessing REIT index or benchmark (Parker, 2011). In the capital markets, real estate has been identified as one of the late entrants in the form of index and benchmark (Property Indexes) developments for measuring performance. The US-NCREIF Property Index was developed in 1978 followed by various other ones (UK-IPD Index, NAREIT Index etc.) (Geltner et al., 2007). Index and benchmark are often used interchangeably and are yardsticks to assessing the performance of an entity. Index measures a defined segment in the stock market (e.g. REIT sector) while benchmark measures specific participant(s) within the market segment (e.g. Office REIT in a REIT sector) (Parker, 2011). Index could also provide a benchmark for participants in a segment. In benchmarking, a clear understanding of the nature of samples that created an index is critical. For instance, the AllShare Index (ASI), or KLCI or American highest capitalised stock index, S\&P 500 or FBMKLCI30 index may not be created by investment/stock of the same characteristics with REIT. Parker (2011) illustrated with UKIPD index which is based on institutional grade commercial real estate of about 11,000-strong sample in the UK. He warned that the sample may not create an index for the entire UK commercial property market because the sample did not include all properties in the market. Such an index is not indicative of the entire real estate market as the sample was defined to represent institutional grade commercial properties in UK (Geltner et al., 2007). By similar argument, a conventional REIT index may not serve a good benchmark for Islamic REIT. Selection of an appropriate index or benchmark is therefore important in order to offer any evidence of abnormal performance (if any). A benchmark needs to be representative of the asset class it measures (Brown \& Matysiak, 2000; Hudson-Wilson \& Wurtzebach, 1994; Parker, 2011). For instance, benchmarking REIT performance with stock market price index that is based solely on share price movement presents a challenge to good judgement on REIT performance. Parker (2011) puts it this way:

"....it is challenging to develop a property portfolio strategy to achieve a goal of top quarter performance without knowing what range of performance the top quartile may comprise. The challenge is magnified by the relevant index being a share price index which, by definition, is based on movement in or performance of share prices. As such performance is yet to occur, reliance has to be placed on forecast of share prices or values requiring some form of assessments of how competing REIT may perform. Effectively, this is akin to the performance forecasting undertaken by equity fund managers or real estate securities managers who may endeavour to select REITs to form a portfolio that will outperform an index or peer group" (pp 49)

Chan et.al. (2003) reported finance literature on the predictability of REIT stock returns that real estate related security performance can be predicted better than small stocks but added that timing is essential (Mei \& Liu, 1994). Karolyi and Sanders (1998) cautioned that REIT return predictability is due to risk premium variation. Cooper et al. (2000) and Nelling \& Gyourko (1998) supported the predictability of REIT return based on past performance. A forecast of return and risk may be a worthy attempt for the development of benchmark and index for REIT performance. Dividend return forecast using past performance record will estimate 
the future period expected return which can serve as benchmark to provide a basis for comparing the actual realised return and measure performance (Brown \& Matysiak, 2000; Parker, 2011). Comparing REIT actual return will reveal underperformance or outperformance for decision making. Outperformance occurs when the actual return is higher than the benchmark while underperformance is a lower actual return to the benchmark.

\subsection{DATA AND METHODOLOGY}

Data for the study comprises the quarterly dividend return series for the period 2006-2013. Out of the 17 REITs in Malaysia, 4 are Islamic REITs and 3 are new entrants to the industry joining between 2010 and 2012. The Islamic REITs and the 3 new entrants were excluded from the study. The data were extracted from the quarterly reports of the 10 REITs selected for the study. The dividend data was processed to form an average dividend for all the selected REITs on quarterly basis over 32 periods (see Table 2).

Table 2: Average dividend distribution for selected REITs

\begin{tabular}{|c|c|c|c|}
\hline Year & Quarter & Period & Dividend (Sen) \\
\hline \multirow[t]{4}{*}{2006} & 1st $(31 / 3 /)$ & 1 & 1.77 \\
\hline & 2nd (30/6) & 2 & 1.68 \\
\hline & 3rd (30/9) & 3 & 1.97 \\
\hline & 4 th $(31 / 12)$ & 4 & 1.60 \\
\hline \multirow[t]{4}{*}{2007} & 1 st $(31 / 3 /)$ & 5 & 1.75 \\
\hline & 2nd (30/6) & 6 & 1.98 \\
\hline & $3 r d(30 / 9)$ & 7 & 2.10 \\
\hline & 4 th $(31 / 12)$ & 8 & 2.43 \\
\hline \multirow[t]{4}{*}{2008} & 1 st $(31 / 3 /)$ & 9 & 2.01 \\
\hline & 2nd (30/6) & 10 & 2.11 \\
\hline & 3 rd (30/9) & 11 & 2.18 \\
\hline & 4th $(31 / 12)$ & 12 & 2.18 \\
\hline \multirow[t]{4}{*}{2009} & 1st $(31 / 3 /)$ & 13 & 2.19 \\
\hline & 2nd (30/6) & 14 & 2.08 \\
\hline & 3rd (30/9) & 15 & 2.26 \\
\hline & 4th $(31 / 12)$ & 16 & 2.55 \\
\hline \multirow[t]{4}{*}{2010} & 1 st $(31 / 3 /)$ & 17 & 2.54 \\
\hline & 2nd (30/6) & 18 & 2.19 \\
\hline & 3rd (30/9) & 19 & 2.05 \\
\hline & 4th $(31 / 12)$ & 20 & 2.13 \\
\hline \multirow[t]{4}{*}{2011} & 1st (31/3/) & 21 & 2.37 \\
\hline & 2nd (30/6) & 22 & 2.21 \\
\hline & $3 r d(30 / 9)$ & 23 & 2.05 \\
\hline & 4th $(31 / 12)$ & 24 & 2.59 \\
\hline \multirow[t]{4}{*}{2012} & 1st (31/3/) & 25 & 2.29 \\
\hline & 2nd (30/6) & 26 & 2.17 \\
\hline & 3rd (30/9) & 27 & 2.07 \\
\hline & 4th $(31 / 12)$ & 28 & 2.19 \\
\hline \multirow[t]{4}{*}{2013} & 1st (31/3/) & 29 & 2.27 \\
\hline & 2nd (30/6) & 30 & 2.31 \\
\hline & 3rd (30/9) & 31 & 2.18 \\
\hline & 4th $(31 / 12)$ & 32 & 2.15 \\
\hline
\end{tabular}

Source: Author's compilation from REITs companies' websites 
For analysis of econometric data and of time and seasonal variance of this nature, time series regression is adjudged the best to establish a linear relationship for a forecast beyond the end of a period for which a data set is collected (Brown \& Matysiak, 2000; Parker, 2011). In the portfolio return analysis, the expected return is the average return of each investment over a defined time period, and in the same vein the expected average dividend return of REITs can be predicted from an analysis of the past actual dividends. Time series regression analysis takes a further step to make adjustment in different distortion known as seasonal effects over a period of time and is adopted for this study. The equation is usually expressed as.

$$
\mathrm{Y}_{\mathrm{t}}=\mathrm{a}+\mathrm{bt}
$$

where $Y_{\mathrm{t}}=$ Expected dividend at period $\mathrm{t}$,

$a=$ the intercept,

$b=$ the slope and

$\mathrm{t}=$ the period of forecast.

\subsection{DATA ANALYSIS AND RESULT}

Table 2 presents the average quarterly dividend distribution of 10 REIT companies for the period 2006 to 2013. In order to make a forecast of the expected return using time series analysis, the data was plotted as a time series data (Figure 2). The data shows elements of randomness, seasonal changes and trend. There is a need to treat the data to remove the irregularity, identify the seasonality and get the trend for time series forecast.

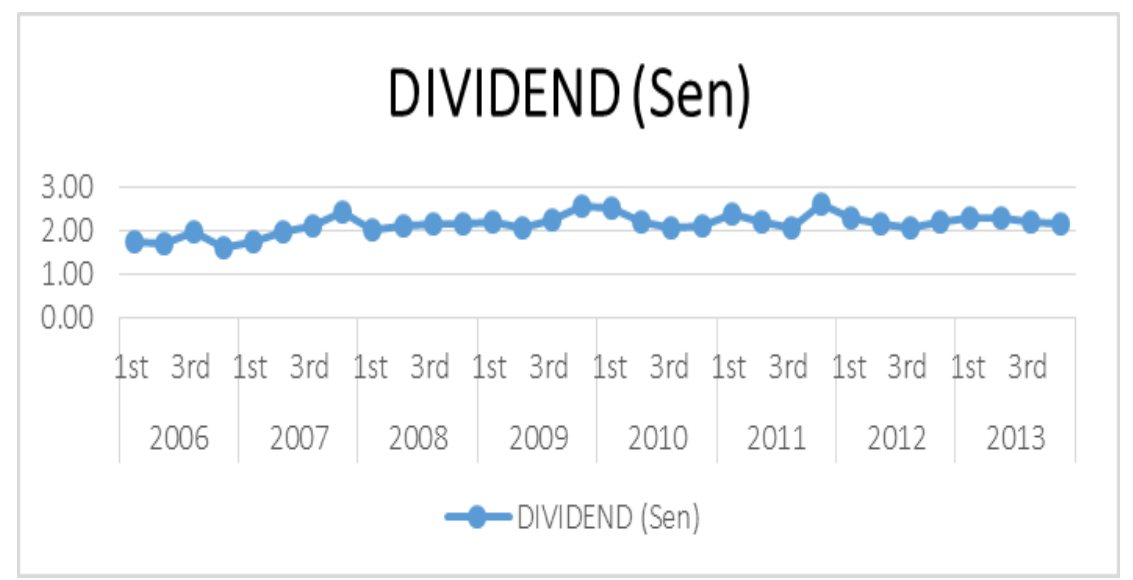

Figure 2: Dividend over the period 2006-2013

The data was smoothed using centralised moving average approach. Table 3 shows the four-quarter moving average (MA), centralised moving average (CMA), seasonality and irregularity components $\left(\mathrm{S}_{\mathrm{t}} \mathrm{I}_{\mathrm{t}}\right)$ and seasonal effect $\left(\mathrm{S}_{\mathrm{t}}\right)$. The smoothed dividend was plotted and overlaid on the actual average dividend (fig. 3)

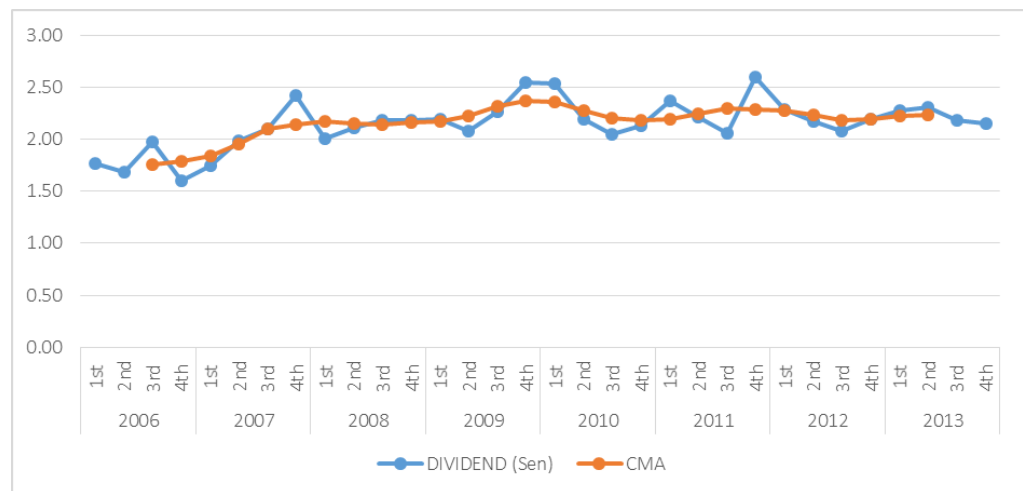

Figure 3: Smoothed dividend overlaid on actual dividend 
Table 3: Time Series data analysis for REIT dividend benchmark forecast

\begin{tabular}{|c|c|c|c|c|c|c|c|c|c|}
\hline Year & Period & $\begin{array}{l}\text { Dividend } \\
\text { (Sen) }\end{array}$ & MA & CMA & St,It & St & $\begin{array}{l}\text { Deseasonalised } \\
\text { dividend } \\
\left(\mathrm{Y}_{\mathrm{t}} / \mathrm{S}_{\mathrm{t}}\right)\end{array}$ & $\begin{array}{l}\text { Trend } \\
\text { Line }\end{array}$ & Forecast \\
\hline \multirow[t]{5}{*}{2006} & 1 & 1.77 & & & & 1.01 & 1.75 & 1.933 & 1.95233 \\
\hline & 2 & 1.68 & & & & 0.98 & 1.72 & 1.946 & 1.90708 \\
\hline & & & 1.76 & & & & & & \\
\hline & 3 & 1.97 & 1.75 & 1.75 & 1.13 & 0.99 & 1.99 & 1.959 & 1.93941 \\
\hline & 4 & 1.60 & 1.82 & 1.79 & 0.89 & 1.03 & 1.55 & 1.972 & 2.03116 \\
\hline \multirow[t]{4}{*}{2007} & 5 & 1.75 & 1.86 & 1.84 & 0.95 & 1.01 & 1.73 & 1.985 & 2.00485 \\
\hline & 6 & 1.98 & 2.06 & 1.96 & 1.01 & 0.98 & 2.02 & 1.998 & 1.95804 \\
\hline & 7 & 2.10 & 2.13 & 2.09 & 1.00 & 0.99 & 2.12 & 2.011 & 1.99089 \\
\hline & 8 & 2.43 & 2.16 & 2.14 & 1.13 & 1.03 & 2.35 & 2.024 & 2.08472 \\
\hline \multirow[t]{4}{*}{2008} & 9 & 2.01 & 2.18 & 2.17 & 0.92 & 1.01 & 1.99 & 2.037 & 2.05737 \\
\hline & 10 & 2.11 & 2.12 & 2.15 & 0.98 & 0.98 & 2.16 & 2.05 & 2.009 \\
\hline & 11 & 2.18 & 2.16 & 2.14 & 1.02 & 0.99 & 2.2 & 2.063 & 2.04237 \\
\hline & 12 & 2.18 & 2.16 & 2.16 & 1.01 & 1.03 & 2.12 & 2.076 & 2.13828 \\
\hline \multirow[t]{4}{*}{2009} & 13 & 2.19 & 2.18 & 2.17 & 1.01 & 1.01 & 2.17 & 2.089 & 2.10989 \\
\hline & 14 & 2.08 & 2.27 & 2.22 & 0.94 & 0.98 & 2.12 & 2.102 & 2.05996 \\
\hline & 15 & 2.26 & 2.36 & 2.31 & 0.98 & 0.99 & 2.29 & 2.115 & 2.09385 \\
\hline & 16 & 2.55 & 2.38 & 2.37 & 1.07 & 1.03 & 2.47 & 2.128 & 2.19184 \\
\hline \multirow[t]{4}{*}{2010} & 17 & 2.54 & 2.33 & 2.36 & 1.08 & 1.01 & 2.51 & 2.141 & 2.16241 \\
\hline & 18 & 2.19 & 2.23 & 2.28 & 0.96 & 0.98 & 2.24 & 2.154 & 2.11092 \\
\hline & 19 & 2.05 & 2.18 & 2.20 & 0.93 & 0.99 & 2.07 & 2.167 & 2.14533 \\
\hline & 20 & 2.13 & 2.19 & 2.19 & 0.97 & 1.03 & 2.06 & 2.18 & 2.2454 \\
\hline \multirow[t]{4}{*}{2011} & 21 & 2.37 & 2.19 & 2.19 & 1.08 & 1.01 & 2.34 & 2.193 & 2.21493 \\
\hline & 22 & 2.21 & 2.31 & 2.25 & 0.98 & 0.98 & 2.25 & 2.206 & 2.16188 \\
\hline & 23 & 2.05 & 2.29 & 2.30 & 0.89 & 0.99 & 2.07 & 2.219 & 2.19681 \\
\hline & 24 & 2.59 & 2.28 & 2.28 & 1.14 & 1.03 & 2.52 & 2.232 & 2.29896 \\
\hline \multirow[t]{4}{*}{2012} & 25 & 2.29 & 2.28 & 2.28 & 1.00 & 1.01 & 2.27 & 2.245 & 2.26745 \\
\hline & 26 & 2.17 & 2.18 & 2.23 & 0.97 & 0.98 & 2.21 & 2.258 & 2.21284 \\
\hline & 27 & 2.07 & 2.18 & 2.18 & 0.95 & 0.99 & 2.09 & 2.271 & 2.24829 \\
\hline & 28 & 2.19 & 2.21 & 2.19 & 1.00 & 1.03 & 2.13 & 2.284 & 2.35252 \\
\hline \multirow[t]{4}{*}{2013} & 29 & 2.27 & 2.24 & 2.23 & 1.02 & 1.01 & 2.25 & 2.297 & 2.31997 \\
\hline & 30 & 2.31 & 2.23 & 2.23 & 1.03 & 0.98 & 2.35 & 2.31 & 2.2638 \\
\hline & 31 & 2.18 & & & & 0.99 & 2.21 & 2.323 & 2.29977 \\
\hline & 32 & 2.15 & & & & 1.03 & 2.09 & 2.336 & 2.40608 \\
\hline \multirow[t]{4}{*}{2014} & 33 & 2.27 & & & & 1.01 & & 2.349 & 2.37249 \\
\hline & 34 & 2.15 & & & & 0.98 & & 2.362 & 2.31476 \\
\hline & 35 & & & & & 0.99 & & 2.375 & 2.35125 \\
\hline & 36 & & & & & 1.03 & & 2.388 & 2.45964 \\
\hline
\end{tabular}

Time series forecast calls for the trend of the line of movement to be established. We recall our equation:

$$
\begin{aligned}
& \mathrm{Y}_{\mathrm{t}}=\mathrm{a}+\mathrm{bt} \\
& \text { (1) }
\end{aligned}
$$

For linear regression, certain assumptions are expected to hold for a valid and acceptable regression.

On the basis of sample size calculation as presented by Krejcie and Morgan (1970), at least 20 cases are required for each independent variable in a regression analysis (Tabachnick \& Fidell, 2007). Since the number of observations is 32 in this study, the size requirement is fulfilled. Also the data is normally distributed since skewness is at -0.342 and kurtosis is at 0.541 .

The regression generated the coefficients for intercept $a$ and slope $b$ to give the trend line equation as follow:

$$
\mathrm{Y}_{\mathrm{t}}=1.92+0.013 \mathrm{t}
$$


Table 4: Regression statistics

\begin{tabular}{ll}
\hline Multiple R & 0.55017837 \\
R Square & 0.30269624 \\
Adjusted R Square & 0.27945279 \\
Standard Error & 0.18887814 \\
Durbin-Watson & 1.583 \\
Observations & 32 \\
\hline
\end{tabular}

The regression statistics gave $R^{2}$ value of 0.30 (Table 4) to suggest that period contributes to $30 \%$ of variation in the dividend, significant at $\mathrm{p}=0.05$ (Table 5). There was a moderate positive relationship between dividend and period as shown by the correlation $(R)$ value of 0.55 (Table 4$)$.

Table 5: Regression coefficient and significant value

\begin{tabular}{ccccccccc}
\hline & & Standard & & & & Upper & Lower & Upper \\
& Coefficient & Error & t Stat & P-value & Lower 95\% & $95 \%$ & $95.0 \%$ & $95.0 \%$ \\
\hline Intercept & 1.9224026 & 0.068375 & 28.11556 & 0.000 & 1.782762157 & 2.062043 & 1.782762 & 2.06204304 \\
PERIOD & 0.01305006 & 0.003616 & 3.60872 & 0.001 & 0.005664678 & 0.020435 & 0.005665 & 0.02043545 \\
\hline
\end{tabular}

The Durbin-Watson statistics test of autocorrelation shows no autocorrelation since the calculated value, at 1.583 , falls between the acceptability range of 1.5 and 2.5 to indicate independence (Table 4). F-statistics from the ANOVA (Table 6) is significant at $p=0.05$. The linear model assumption of efficiency requires the test for homoscedasticity disturbance which is related to residual normality (Breusch \& Pagan, 1979). The Breusch-Pagan test uses F-statistics to test for homoscedasticity (Renfro, 2009). The calculated F-statistics in this study, at 13.023, is greater than the critical F-value of 5.117; thus, there was no evidence of heteroscedasticity. This can be further confirmed by a visual inspection of the residual scatter plot (Figure 3 ).

Table 6: ANOVA

\begin{tabular}{llllcl}
\hline & df & SS & MS & F & Significance F \\
\hline Regression & 1 & 0.46459 & 0.46459 & 13.02286 & 0.001105069 \\
Residual & 30 & 1.070249 & 0.035675 & & \\
Total & 31 & 1.534838 & & & \\
\hline
\end{tabular}

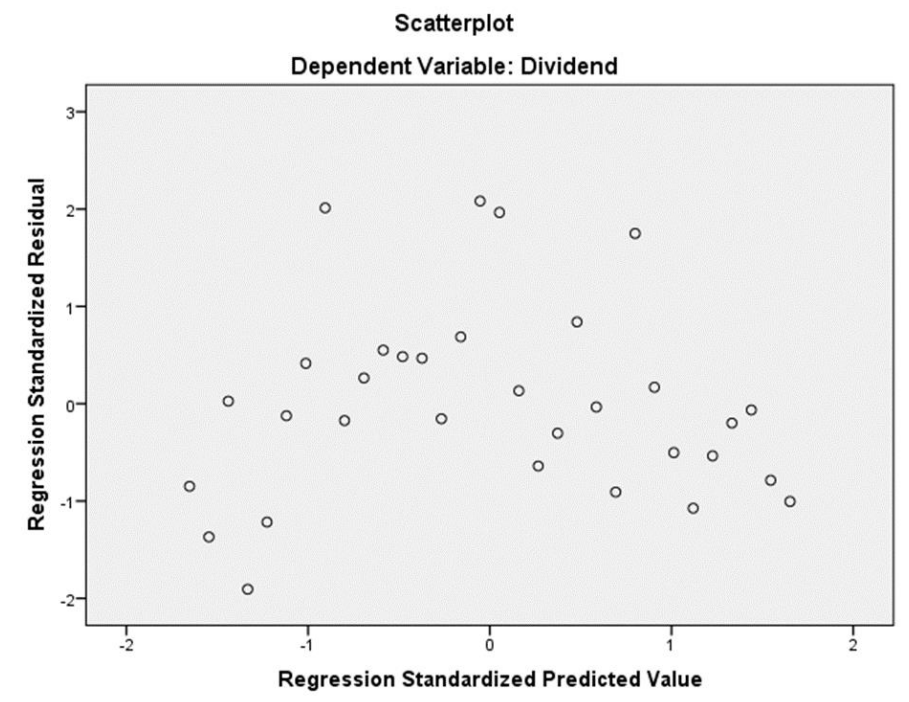

Figure 4: Scatterplot of residual and predicted values. 
From the above scatterplot (Figure 4), there is no identifiable pattern of the distribution of the residuals. This validates the regression. The linearity assumption of the relationship between the dividend and period is presented with the Normal Probability Plot (P-P) as shown in Figure 5.

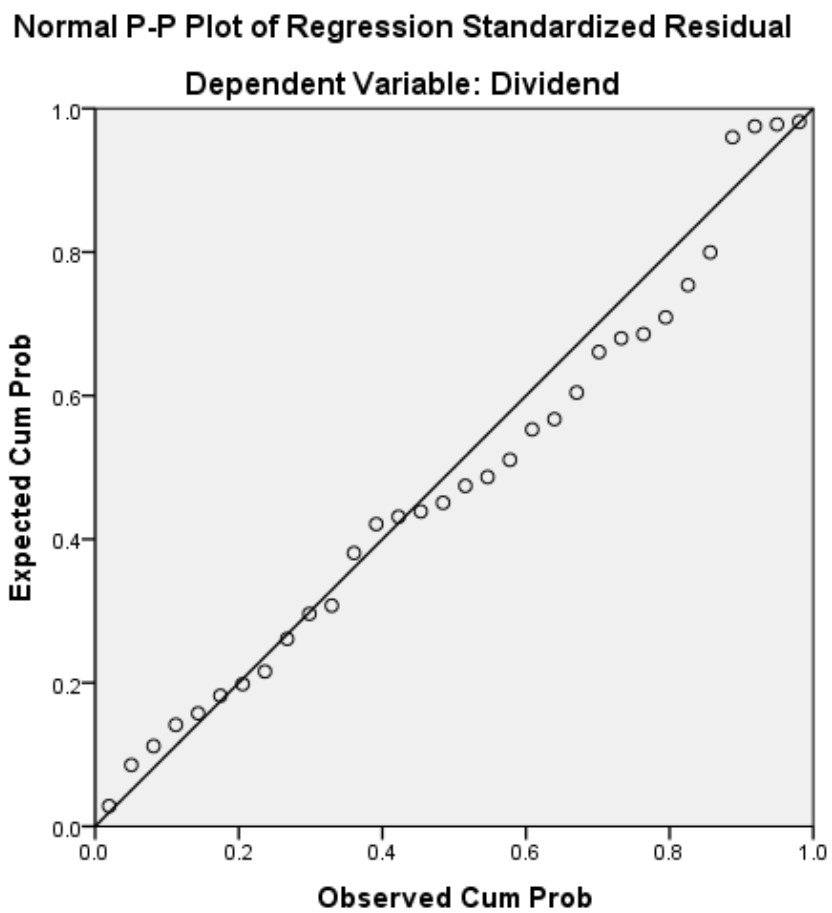

Figure 5: Linearity curve

The regression equation was used to calculate the expected dividend in the column labelled "Trend Line" in Table 3 . The values were multiplied with the corresponding value of seasonal components to make the forecast of dividend in the extreme right column of Table 3. The forecast was extended to the four quarters of the year 2014 and the predicted return was plotted and overlaid over the observed average return and the smoothed return (CMA) (Figure 6).

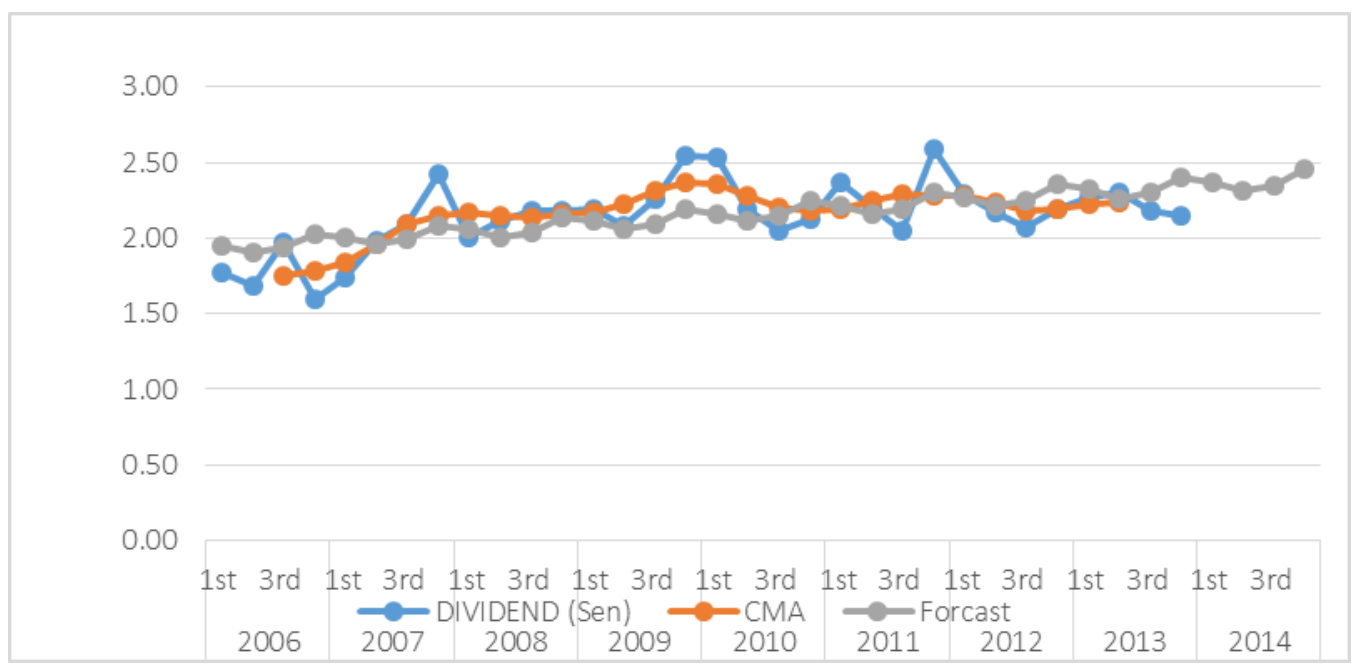

Figure 6: Dividend forecast overlaid on observed and smoothed dividends 
Table 7: Malaysia REIT average yield as at 30-Jun-14 (6.885\%)

\begin{tabular}{lllllll}
\hline REIT & Period & $\begin{array}{l}\text { DPU } \\
(\text { Sen })\end{array}$ & $\begin{array}{l}\text { Price } \\
(\mathrm{RM})\end{array}$ & Yield & $\begin{array}{l}\text { NAV } \\
(\mathrm{RM})\end{array}$ & Assets Type \\
\hline YTL Hospitality & Q3 - Mar14 & 2.0804 & 0.915 & $9.095 \%$ & 0.9953 & Diversified \\
Reit & 2H - Mar14 & 3.7000 & 0.945 & $7.831 \%$ & 1.2381 & Office \\
AmFirst & 2H - Dec13 & 5.3900 & 1.380 & $7.812 \%$ & 1.4992 & Office \\
UOA & Q1 - Mar14 & 1.7000 & 0.915 & $7.743 \%$ & 1.0216 & Retail \\
AmanahRaya & 2H - Dec13 & 5.6100 & 1.420 & $7.535 \%$ & 1.7984 & Office \\
Tower & 2H - Dec13 & 4.2800 & 1.170 & $7.162 \%$ & 1.3458 & Office \\
Quill Capita & Q1 - Mar14 & 2.2000 & 1.260 & $6.984 \%$ & 1.3503 & Industrial \\
Atrium & Q1 - Mar14 & 2.6000 & 1.510 & $6.887 \%$ & 1.5301 & Retail \\
Hektar & Q1 - Mar14 & 5.3000 & 3.310 & $6.405 \%$ & 2.2317 & Office \\
Axis & 2H - Dec13 & 4.5000 & 1.480 & $6.081 \%$ & 1.1960 & Malls \\
CMMT & 2H - Dec13 & 3.6100 & 1.220 & $5.918 \%$ & 1.0643 & Malls \\
IGB REIT & Q1 - Mar14 & 2.1000 & 1.440 & $5.833 \%$ & 1.1787 & Diversified \\
Sunway & 2H - Dec13 & 3.9900 & 1.400 & $5.607 \%$ & 1.1520 & Plantation \\
Al-AQAR & 2H - Dec13 & 3.7100 & 1.350 & $5.496 \%$ & 1.1522 & Malls \\
Healthcare & Sourc:Marian & \\
Pavilion & & & & & \\
\hline
\end{tabular}

Source: Malaysia REIT: All about Malaysia REITs (2014)

\subsection{DISCUSSION OF FINDING}

The set goal of this paper has been to establish a benchmark for REIT performance measurement through a forecast that will take into consideration the time series nature of the data and investment return. The data was a quarterly collected average of the actual dividend distribution of 10 selected REITs in Malaysia. The study found that the actual dividend inherited attributes of irregularity, seasonality and trend. The data was smoothed using centralised moving average (CMA) and the extraction of the seasonal and irregular components of the data. The regression for the trend estimation generated an intercept of 1.92 and a slope of 0.013 . Period explained $30 \%$ of the variation in dividend $\left(R^{2}=0.30\right)$ at $\mathrm{p}=0.05$ significance level. The predicted dividend showed a curve that closely followed the smoothed dividend. The forecast for year 2014 revealed a final annual dividend of 9.498 Sen per unit (Table 3 and Figure 6). At unit price of RM1 (using the initial public offer - IPO price of most REITs in Malaysia), the expected return as forecasted and which is presented as the benchmark in this study is 9.5\%. An examination of the REITs returns in Table 7 showed that the average REIT return in Malaysia for the first half of the year was $6.885 \%$. A closer look at the table shows that only one out of the listed REITs in Malaysia (YTL REIT) was close to the predicted return with 9.05\%. This implies that M-REIT underperforms its sectoral benchmark if the expected return serves as the benchmark for the sector (27.5\% lower than the predicted return).

The KLCI, often used as a benchmark, notched 5.5\% for the year 2013. Comparing the REITs return of September 2013 (6.26\%) with September KLCI (5.3\%), REITs outperformed the KLCI but below the 2013 predicted return of 9.27\% for the REIT sector (Table 3). The Malaysian REIT return of 6.89\% for the first half of year 2014 (Table 7) was also an underperformance compared with the prediction of $9.5 \%$ for the year. Therefore M-REIT outperformed the KLCI but had a sectorial capacity underperformance.

\subsection{CONCLUSION}

This study has examined the adequacy of the adopted benchmark for Malaysia REIT sector performance (the KLCI) and found REIT outperforming the benchmark. The peculiar nature of the underlying asset of REITs which is real estate asset with its heterogeneous nature has also been taken into consideration. The study is of the view that although REIT is a stock (capital market) investment, a sectoral benchmark that will reflect the real estate characteristics in the performance should be desirable. A time series regression of the past performance of the sector is thus advocated. Given the individual capacity of the REIT firms (as may be reflected by the economic variables of NAV, size and income) and the heterogeneity of property market (which could be reflected in the yearly dividend distribution), the study propose that a sector forecast of expected return with consideration of necessary adjustment for seasonality and randomness will go a long way toward reflecting the full potential of REIT companies for an optimum performance of the REITs. The study concludes that a forecast of the expected return is a more reliable benchmark for REIT performance. 
This study's focus on dividend-based return is grounded on the premise that investors as speculators or traders attracted not only by the price movement of stock prices but also by the performance of the REITs funds as revealed in their dividend distribution history. Price gain can be considered as reward for risks taken to invest in an investment vehicle/asset (a subject of future research). Some REITs do distribute dividend amidst unit price fall. The study also relied (for the validity of the regression) on the autocorrelation and heteroscedasticity tests but the unit root test for stationarity was not performed.

\subsection{REFERENCES}

Ahmad, H. H., Mohammad, B. R., \& Izah, M. T. (2010). Empirical investigation on the performance of the Malaysian real estate investment trusts in pre-crisis, during crisis and post crisis period. International Journal of Economics and Finance, 2(2) $62-69$.

Alias, A., \& Soi Tho, C. Y. (2011). Performance analysis of REITS: Comparison between M-REITS and UK-REITS. Journal of Surveying, Construction and Property, 2 (Special issue), 38-61.

Breusch, T. S., \& Pagan, A. R. (1979). A simple test for heteroscedasticity and radom coefficient variation. Econometrica, 47(5), 1287-1994.

Brown, G. R., \& Matysiak, G. A. (2000). Real estate investment: A capital market approach. Harlow: Financial Times Prentice Hall.

Bursa Malaysia Securities (2013, December). Real estate investment trusts (REITs): REIT List. Retrieved December 20, 2013 from, http://www.bursamalaysia.com/market/

Chan, K. C., Hendershott, P. H., \& Sanders, A. B. (1990). Risk and return on real estate: Evidence from equity REITs. Real Estate Economics, 18(4), 431-452.

Chan, S. H., Erickson, J., \& Wang, K. (2003). Real estate investment trusts: Structure, performance and investment opportunities. New York, USA: Oxford University Press.

Collier, N. (2013). Real estate investment trust: Structure of REIT. Legacy Investment Properties. Retrieved January 5, 2014 from, http://kclegacygroup.com/reits-real-estate-investment-trust/

Cooper, M., Downs, D. H., \& Patterson, G. A. (2000). Asymmetric information and the predictability of real estate returns. Journal of Real Estate Finance and Economics, 20(2), 225-244.

Corgel, J. B., Mclntosh, W., \& Ott, S. H. (1995). Real estate investment trusts: A review of the financial economics literature. Journal of Real Estate Literature, 3, 13-43.

Cunningham, R., \& Ramey, J. M. (2006, September 12-18). Real estate investment trusts (REITs) and development: Avoiding qualification woes. Financial Digest. Retrieved from, http://www.hf-law.com/images/uploads/CunninghamRamey.pdf

EPRA. (2012). Global REIT survey, South Africa PUT and PLS company. EPRA reporting. Earnst and Young. Retrieved from, http://www.epra.com/regulation-and-reporting/taxation/reit-survey/

EPRA. (2014). Global REIT survey 2014: European Public Real Estate Association. Retrieved from, http://www.epra.com/regulation-and-reporting/taxation/reit-survey/

FMI. (2010). Real estate investment trusts: Is the Philippines ready? Capital Research: First Metro Investment Corporation.

Geltner, D. M., Miller, N. G., Clayton, J., \& Eighholtz, P. (2007). Commercial real estate analysis and investment. South Western, Mason: Thomson.

Grupe, M. R., \& DiRocco, C. J. (1999). The NAREIT index of REIT industry performance. Real Estate Finance, 16(1), 21-50.

Han, J., \& Liang, Y. (1995). The historical performance of real estate investment trusts. Journal of Real Estate Research, 10(3), 235262.

Havsy, J. (2012). NCREIF - NAREIT Executive Summary Report. Retrieved from, http://www.ncreif.org/

Hiriyappa, B. (2008). Investment management: Securities and portfolio management. New Delhi: New Age.

Hoesli, M., \& Lizieri, C. (2007). Real estate in the investment portfolio. A report for the investment strategy council (pp. 94-95). Norway: Ministry of Finance.

Hudson-Wilson, S., \& Wurtzebach, C. (1994). Managing real estate portfolios. Burr Ridge: Irwin.

Hwa, T. K. (2008). Sources of net present value gains in the acquisitions of corporate real estate. Journal of Corporate Real Estate, 10(2), 121-129.

Hwa, T. K. (2009). Impact of single-tier taxation system on dividend returns of indirect property investment in Malaysia. Journal of Valuation and Property Sciences, 9(1). Retrieved from, http://www.inspen.gov.my/inspen/v2/wpcontent/uploads/2009/12/Abstract-JVPS-2009.pdf

Kapplan, S. D., \& Schwartz, A. L. (1995). Recent performance of US real estate securities: Alternative ideas in real estate investment (pp. 5-18). Norwall, CT: Kluwer Academic Publisher.

Karolyi, G. A., \& Sanders, A. B. (1998). The variation of economic risk premiums in real estate returns. Journal of Real Estate Finance and Economics, 17(3), 245 - 262. 
Kotler, P. (1984). Marketing management analysis, planning and control. Engelwood Clliffs, NJ: Prentice Hall.

Krejcie, R. V., \& Morgan, D. W. (1970). Determining sample size for research activities. Educational and Psychological Measurement, 30, 607-610.

Lee, A., Gregory, M., \& Platts, K. (2005). Performance measurement system design: A literature review and research agenda. International Journal of Operations and Production Management, 25(12), 1228-1263.

Lee, C. L., \& Ting, K. H. (2009). The role of Malaysian securitised real estate in a mixed asset portfolio. Journal of Financial Management of Property and Construction, 14(3), 208-230.

Malaysia REITs (2014). Malaysia REITs: All about Malaysia REITs. Retrieved January 7, 2015 from, http://mreit.reitdata.com/

Mei, J., \& Liu, C. (1994). The predictability of real estate returns and market timing. Journal of Real Estate Finance and Economics, $8(2), 115-135$.

Neely, A. D. (1994). Performance easurement system design - Third Phase. (In Neely et al, 2005), Performance measurement system design. International Journal of Operations and Management, 25(12), 1228-1263.

Nelling, E., \& Gyourko, J. (1998). The predictability of equity REIT returns. Journal of Real Estate Research, 16(3), 251 - 268.

Newell, G., \& Osmadi, A. (2009). Development and preliminary performance of Islamic REIT in Malaysia. Journal of Property Research, 26(4), 329-347.

Newell, G., Ting, K. H., \& Archeampong, P. (2002). Listed property in Malaysia. Journal of Real Estate Literature, 10, 109-118.

Okunev, J., \& Wilson, P. J. (2008). Predictability of equity REIT returns: Implication for property tactical asset allocation. International Real Estate Review, 11(2), 32-46.

Ong, T. S., The, B. H., \& Chong, M. P. (2011). A study on the performance of Malaysian real estate investment trusts from 20052010 by using net asset value approach. International Journal of Economics Research, 2(1), 1-15.

Ong, T. S., The, B. H., Soh, C. H., \& Yan, Y. L. (2012). Malaysian real estate investment trusts: A performance and comparative analysis. International Journal of Economics and Finance, 4, 73-84.

Ooi, J. T. L., \& Liow, K. H. (2003). Risk adjusted performance of real estate stock: Evidence from emerging markets in Asia. Paper presented at the American Real Estate and Urban Economics Association Annual Conference and Meeting, Washington D. C.

Oreagba, F. (2010). Position paper on implementation of REIT in Nigeria (N-REIT). A seminar on Real Estate Investment Trust (REIT): Nigerian Stock Exchange.

Osmadi, A. (2007). A new property dimension to Islamic finance. Paper presented at the 13th Pacific Rim Real Estate Society (PRRES) Conference, Fremantle, Australia.

Parker, D. (2011). Global real estate investment trusts: People, process and management. West Sussex, United Kingdom: Wiley Blackwell.

Peng, H. W., \& Newell, G. (2012). The role of Taiwan REITs in investment portfolio. Pacific Rim Property Research Journal, 18(1), 67-80.

Pham, A. K. (2013). An empirical analysis of real estate investment trusts in Asia: Structure, performance and strategic investments implications (PhD Thesis). University of Western Sydney, Australia.

Renfro, C. G. (2009). The practice of econometric theory: An examination of the characteristics of econometric computation. USA: Springer.

Slack, N. (1991). The manufacturing advantage. achieving competitive manufacturing operations. London: Mercury.

Tabachnick, B. G., \& Fidell, L. S. (2007). Using multivariate statistics. Boston: Allyn and Bacon.

Titman, S., \& Warga, A. (1986). Risk and the performance of real estate investment trusts: A multiple index approach. The Journal of the American Real Estate and Urban Economics Association, 14(3), 414-431.

Wong. (2004). REIT return and property types (Master thesis). National Center University. 